\title{
Winter UTCI variability in Poland in the 21st century
}

\begin{abstract}
The study analyses spatial and temporal variability of the UTCI index during winter seasons in Poland in the 21st century. The most frequent UTCI thermal stress category was moderate cold stress with a frequency varying from $45.8 \%$ in Łeba (Coastal region) to $66.1 \%$ in Zielona Góra (Central region). In mountain areas, this class was less frequent (7.3$12.3 \%)$. The second most frequent class was strong cold stress with values from $11.1 \%$ in Zakopane (Carpathian region) to $43.4 \%$ in Suwałki (North-East region). In mountain areas, very strong cold stress and extreme cold stress occurred frequently $(25.0-35.5 \%$ and $17.7-52.0 \%$, respectively). Few cases of extreme cold stress were observed on other Polish stations. Thermoneutral zone was not recorded in the mountain area, although on other Polish stations its frequency ranged from $0.1 \%$ in Chojnice, Suwałki and Białystok located in northern part of Poland to $4.3 \%$ in Zakopane (Carpathian region).
\end{abstract}

Keywords

$\mathrm{UTCl} \cdot$ Universal Thermal Climate Index $\cdot$ biothermal conditions $\cdot$ cold stress $\cdot$ winter season $\bullet$ Poland

(C) University of Warsaw - Faculty of Geography and Regional Studies
Sylwester Wereski $\mathbb{C}$, Agnieszka Krzyżewska $\mathbb{C}$, Mateusz Dobek $\mathbb{0}$

Department of Hydrology and Climatology,

Faculty of Earth Sciences and Spatial Management.

University of Maria Curie-Skłodowska in Lublin, Lublin, Poland

e-mail: sylwester.wereski@umcs.pl

e-mail: krzyzewska.agnieszka@gmail.com

e-mail: mateusz.dobek@gmail.com

Received: 3 November 2019

Accepted: 29 June 2020
Introduction

According to the authors of the 5th IPCC Report (2014), weather extremes related to low temperatures will be less frequent and less intensive, though they will still occur. Although the last extremely cold winter in Europe in the 20th century was recorded in the 1984/1985 season, the phenomenon occurred again after 25 years in the 2009/2010 season, in spite of progressing climate warming, and was described as a cold extreme in a warming climate' (Cattiaux et al. 2010; Twardosz \& Kossowska-Cezak 2016). Despite falling to a minimum in the years 1990-2000, the number of extremely cold winter months has been growing since the beginning of the 21st century (Twardosz et al. 2016). Shorter cold periods, called cold waves or cold spells, still result in numerous deaths and contribute to a higher number of road accidents and injuries, including broken bones. They also cause damage to road and railway infrastructure and constrain river transport. The occurrence of periods of low air temperature results in an increase in the demand for heat energy (Healy 2003; Vajda et al. 2014; Mladenović et al. 2017). In recent years, such phenomena occurred at the turn of February and March 2018 in Great Britain (described as the 'Beast from the East'), and in January 2017 in central, southern, and eastern Europe (Anagnostopoulou et al. 2017; Schulze et al. 2018).

In Poland in the 20th century, regional variability of the number of frosty days was observed. The highest number of such days occurred in the eastern part of the country and in the mountains, and the lowest at the coast (Cebulak \& Limanówka 2007). The cold spells in Poland are usually related to more active and intensive pressure systems, especially with strong high-pressure systems and blocking westerly circulation (Tomczyk et al. 2019).
Cold waves, covering almost the entire territory of the country in recent years, were recorded in January 2006, December 2009 and January 2010 (Krzyżewska \& Wereski 2011). After 2010, there were some strong cold spells in January/February 2012 (Tomczyk et al. 2019), January 2017 (Krzyżewska et al. 2019) and February/ March 2018. Due to the latter cold wave, those two months in 2018 were an anomaly and were colder than the multi-annual mean; the rest of the year was warmer (Tomczyk \& Bednorz 2019).

The human organism, subject to an atmospheric environment with negative air temperature, and often high relative humidity and the occurrence of wind, runs the risk of hypothermia. One of the mechanisms of thermoregulation in such conditions is to wear clothing with appropriate thermo-insulation properties. This does not solve the problem, however, because some body parts may stay uncovered, running the risk of frostbite. In countries such as Canada and the United States, preventive communications are issued in the winter season, providing information on the risk related to spending time in open areas and to the potential consequences (Błażejczyk \& Kunert 2011). In Poland such information, together with short-term biometeorological forecasts, is presented by the Institute of Meteorology and Water Management - National Research Institute through their webservice - pogodynka.pl. However, despite the warnings, most cold-related deaths caused by hypothermia occur not during the cold wave itself but at the beginning of the cold season, when the human body has not yet adapted to the cold environment. Yet, even in the 21st century, with the rising global temperature due to climate change, many people die from hypothermia - a cause of death that is fully preventable (Krzyżewska et al. 2017). 


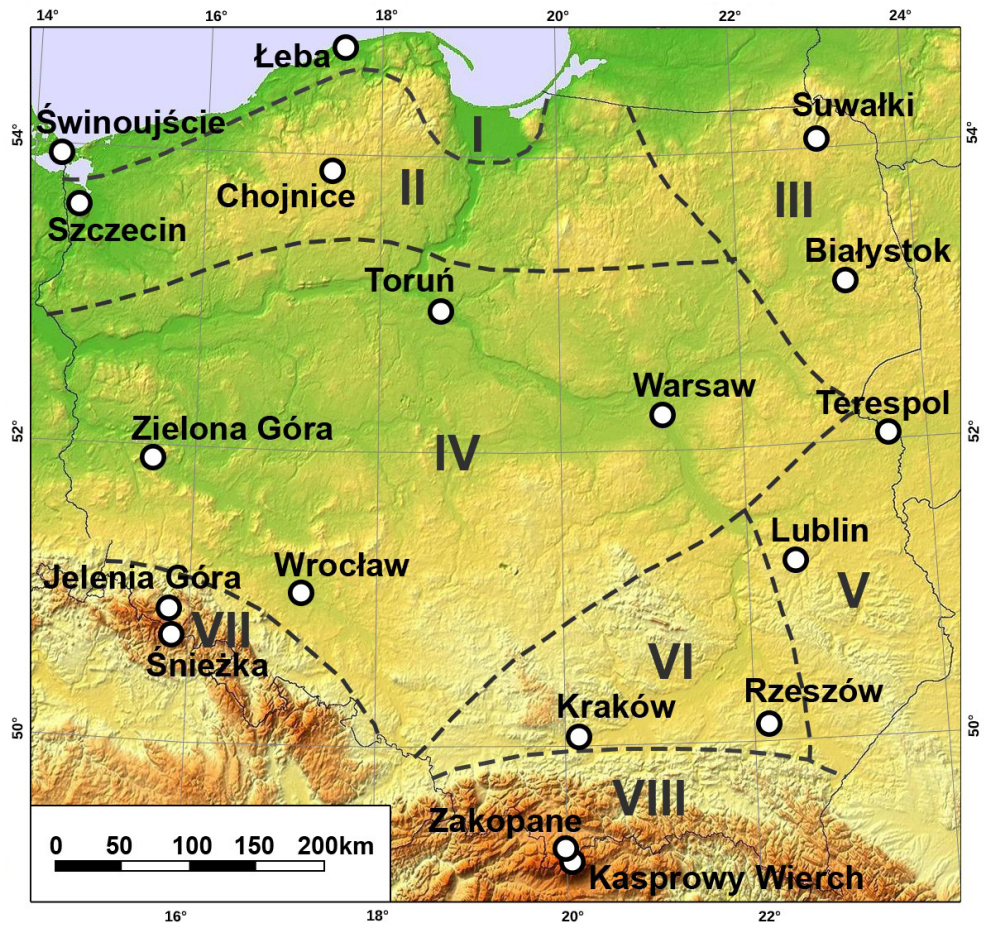

Figure 1. Location of meteorological stations used for this study against the background of bioclimatic regions, following K. Błażejczyk (Błażejczyk \& Kunert 2011). Names of bioclimatic regions are presented in Table 1

The assessment of biometeorological conditions currently involves the application of advanced indices based on the human heat balance equation. Such indices include the Universal Thermal Climate Index (UTCl), developed as a result of the collaboration of an international research team within the scope of COST Action 730 (eds. Jendritzky et al. 2009; Jendritzky et al. 2012). The index was used in the description of bioclimatic conditions in selected regions of Poland (Chabior 2011; Mąkosza 2013; Milewski 2013; Kolendowicz et al. 2018; Koźmiński \& Michalska 2019; Owczarek 2019; Owczarek et al. 2019; Tomczyk \& Owczarek 2019), but it was also applied in studies in different regions of the world (Provençal et al. 2016; Ge et al. 2017; Mohammadi et al. 2018).

The objective of this paper is the temporal and spatial analysis of bioclimatic conditions in Poland during the winter season. The situations of recorded occurrences of thermal stress, from strong cold stress to extreme cold stress, are described using basic descriptive statistics (minimum, maximum, mean, and bottom and top quartile). The special focus is on the frequency of occurrence of biothermal conditions that cause strong cold stress. Due to contemporary climate change, such situations now occur less frequently in Poland. The positive aspect of such a trend is the lower risk of cold-related diseases such as flu infections, or fewer deaths from hypothermia (Błażejczyk et al. 2015). However, in the case of the occurrence of such conditions, society may not be well adapted, and health consequences may be much more severe.

\section{Material and methods}

The description of bioclimatic conditions in Poland in the winter season employed term data (air temperature, relative humidity, wind speed, and cloudiness) from 12 UTC - an observation term most representative of human activity (Kozłowska-Szczęsna et al. 1997). The winter season was defined as three subsequent months: December of the preceding year, and January and February of the following year. This analysis was carried out for the $2001 / 2002-2017 / 2018$ seasons. Data were obtained from 18 meteorological stations at the Institute of Meteorology and Water Management - National Research Institute (Fig. 1). The choice of stations provided for complete data sequences, the representation of all biometeorological regions of Poland (Błażejczyk \& Kunert 2011), and the even distribution of points in the territory of the country.

In the first stage, the presentation of the climatic background involved the analysis of mean seasonal values of selected meteorological elements - air temperature, relative humidity, wind speed, and cloudiness - at 12 UTC. Biometeorological conditions were determined using the UTCI index, based on Fiala's multinodal model of heat exchange between the human organism and the atmospheric environment (Fiala at al. 2001, 2012). The index is defined as the 'air temperature of the reference conditions causing the same model response as actual conditions' (Błażejczyk et al. 2013). The calculation of the UTCI value employs a power of six exponential function taking the following form:

$\mathrm{UTCl}=\mathrm{f}(\mathrm{Ta}$, Tmrt, va, vp $)$

where: Ta - air temperature $\left[{ }^{\circ} \mathrm{C}\right]$; vp - water vapour pressure [hPa]; va - wind speed at a height of $10 \mathrm{~m}$ a.g.l. [m. $\mathrm{s}^{-1}$; Tmrt - difference between mean radiation temperature (Mrt), and air temperature $\left[{ }^{\circ} \mathrm{C}\right]$.

In this article, the authors calculated the UTCI value using BioKlima ver. 2.6 (IGiPZ PAN 2019) software. Because measurements of the intensity of solar radiation, required for the determination of the value of mean radiation temperature (Mrt), were not conducted in every station, the authors decided to use information on cloudiness in the calculations, and to apply the radiation model implemented in the BioKlima software. In all cases, when wind speed was equal to $0 \mathrm{~m} \cdot \mathrm{s}^{-1}$, the $0.5 \mathrm{~m} \cdot \mathrm{s}^{-1}$ value was adopted, and when it exceeded $20 \mathrm{~m} \cdot \mathrm{s}^{-1}$, the $20 \mathrm{~m} \cdot \mathrm{s}^{-1}$ value 
MISCELLANEA GEOGRAPHICA - REGIONAL STUDIES ON DEVELOPMENT

Vol. $24 \cdot$ No. 3 • 2020 • pp. 128-137 • ISSN: 2084-6118 • DOI: 10.2478/mgrsd-2020-0021

Table 1. Assessment scale of UTCI

\begin{tabular}{|c|c|c|}
\hline UTCI $\left({ }^{\circ} \mathrm{C}\right)$ & Heat stress category & Recommendations for protection \\
\hline$>46.0$ & extreme heat stress EHS & periodical cooling and drinking $>0.5 \mathrm{I} \cdot \mathrm{h}^{-1}$ necessary; stay inactive \\
\hline $38.1-46.0$ & very strong heat stress VSHS & $\begin{array}{c}\text { periodical use of air conditioning or shaded sites, and drinking }>0.5 \mathrm{I} \cdot \mathrm{h}{ }^{-1} \\
\text { necessary; reduce activity }\end{array}$ \\
\hline $32.1-38.0$ & strong heat stress SHS & drinking $>0.25 \mathrm{I} \cdot \mathrm{h}^{-1}$ necessary; keep to shady places and reduce activity \\
\hline $26.1-32.0$ & moderate heat stress MHS & drinking $>0.25 \mathrm{I} \cdot \mathrm{h}^{-1}$ necessary \\
\hline $9.1-26.0$ & thermoneutral zone TZ & physiological thermoregulation sufficient to stay comfortable \\
\hline $0.1-9.0$ & slight cold stress SICS & increase activity; protect extremities and face against cooling \\
\hline$-12.9-0.0$ & moderate cold stress MCS & clothing \\
\hline$-26.9--13.0$ & strong cold stress SCS & strongly increase activity; protect face and extremities; use better insulated \\
\hline$-39.9--27.0$ & very strong cold stress VSCS & strongly increase activity; protect face and extremities; use better insulated \\
clothing; reduce time outdoors
\end{tabular}

Source: Błazejczyk et al. 2013

was adopted. Such a solution is due to problems concerning the calculation of the UTCI index for selected wind speeds, as mentioned by Nowak (2013).

In addition to the temporal and spatial variability of particular thermal conditions that were determined based on UTCI (Table 1 ), the measures of the location (top and bottom quartile) and range (maximum and minimum values) were also traced for cases with classes from strong to extreme cold stress.

\section{Climatic conditions of the winter season}

Bioclimatic conditions are defined as a group of atmospheric stimuli collectively affecting the human organism. Meteorological elements usually considered in the bioclimatic assessment include air temperature, relative humidity, wind speed, and solar radiation intensity, which depends on cloudiness among other things. The spatial variability of the values of the elements in the territory of Poland in the winter season analysed is worth mentioning.

Mean seasonal (DJF) air temperature value at 12 UTC varied from $-6.7^{\circ} \mathrm{C}$ at Kasprowy Wierch station to $2.5^{\circ} \mathrm{C}$ in Wrocław. A value somewhat higher than that recorded on Kasprowy Wierch was observed on another high mountain station - Śnieżka, at $-5.4^{\circ} \mathrm{C}$. In the lowland part of the country, low air temperature values were observed on stations representing the North-East region, in Suwałki $\left(-1.6^{\circ} \mathrm{C}\right)$, and Białystok $\left(-0.9^{\circ} \mathrm{C}\right)$. Negative values of mean seasonal air temperature at 12 UTC were also recorded at the stations of the South-East region: Lublin $\left(-0.4^{\circ} \mathrm{C}\right)$ and Terespol $\left(-0.4^{\circ} \mathrm{C}\right)$, as well as at the Zakopane station $\left(-0.1^{\circ} \mathrm{C}\right)$, located in the Carpathian region (Table 2). Approximate results were presented by Błażejczyk and Kunert (2011) for the multiannual period 1971-1990. According to the authors, in the winter season, the North-East region is the coldest, and the Coastal and Upland regions are the warmest. In the analysed period, lower seasonal air temperature values occurred in 2002, 2005, 2009, 2010 and 2012, and higher temperature values occurred in 2006, 2007, 2013 and 2015.

Mean seasonal relative humidity values in winter at 12 UTC in the analysed multi-annual period varied from $71.2 \%$ in
Zakopane and 74.3 in Jelenia Góra to $86.2 \%$ in Suwałki. Lower air humidity was observed at the stations in the Upland region (79.0-79.3\%), and this was higher in northern Poland where, in the Coastal and Lakeland regions, the seasonal relative humidity value varied from $80.9 \%$ in Szczecin to $85.9 \%$ in Chojnice (Table 2). Annually, in Poland, the highest values of the elements are recorded in winter months. A different annual course of relative humidity is observed in mountain areas. In the Carpathians and Sudetes, the highest relative humidity occurs in late spring and in summer; in winter short-term decreases in humidity are recorded in the mountains, related to Foehn wild circulation, when mean daily humidity values do not exceed $30-40 \%$ (Woś 2010).

Cloudiness in the winter season varied at the analysed stations from 5.6 octanes in Świnoujście to 6.6 octanes in Chojnice, Białystok, and Terespol (Table 2). According to Błażejczyk and Kunert (2011), Świnoujście is a station that shows no seasonal variability of cloudiness, and in the north, north-east, and central Poland in winter, the annual maximum of the value occurs. In the Carpathian and Sudetic regions, cloudiness is lower than in the remaining regions of the country. This is confirmed by data from Zakopane and Kasprowy Wierch, where mean the seasonal cloudiness values were 5.9 and 6.0 octanes, respectively (Table 2).

Both the lowest and highest mean wind speed in the winter season at 12 UTC occurred at stations located in mountain regions. In mountain valleys - in Zakopane $\left(2.0 \mathrm{~m} \cdot \mathrm{s}^{-1}\right)$ and Jelenia Góra $\left(3.4 \mathrm{~m} \cdot \mathrm{s}^{-1}\right)$ - the lowest wind speed value was recorded, and the highest was found on high mountain stations - Kasprowy Wierch $\left(7.4 \mathrm{~m} \cdot \mathrm{s}^{-1}\right)$ and Śnieżka $\left(14.2 \mathrm{~m} \cdot \mathrm{s}^{-1}\right)$. The variability is due to the diverse land relief characteristics of mountain areas. In the lowland part of the country, high wind speed was observed in the north, in Łeba $\left(5.8 \mathrm{~m} \cdot \mathrm{s}^{-1}\right)$ and other parts of the Coastal region, as well as in Chojnice $\left(4.6 \mathrm{~m} \cdot \mathrm{s}^{-1}\right)$ and Szczecin $\left(4.7 \mathrm{~m} \cdot \mathrm{s}^{-1}\right)$ in the Lakeland region. High wind speed was also observed in Rzeszów in the Upland region. Its value was $5.2 \mathrm{~m} \cdot \mathrm{s}^{-1}$ (Table 2). In Poland, the highest wind speed values occur in winter months. This is explained with the occurrence of greater gradients of atmospheric pressure during this period (Paszyński \& Niedźwiedź 1999). 
Table 2. Mean seasonal (DJF) values of selected meteorological elements at 12.00 UTC in Poland, 2001/02 - 2017/18

\begin{tabular}{|c|c|c|c|c|c|}
\hline Name and number of region & Name of station & $\mathrm{t}\left[{ }^{\circ} \mathrm{C}\right]$ & $f[\%]$ & N [octant] & $\mathbf{v}\left[\mathbf{m} \cdot \mathbf{s}^{-1}\right]$ \\
\hline \multirow{2}{*}{ Coastal (I) } & Łeba & 1.7 & 81.9 & 6.3 & 5.8 \\
\hline & Świnoujście & 2.2 & 83.3 & 5.6 & 3.5 \\
\hline \multirow{2}{*}{ Lakeland (II) } & Szczecin & 2.4 & 80.9 & 6.3 & 4.7 \\
\hline & Chojnice & 0.2 & 85.9 & 6.6 & 4.6 \\
\hline \multirow{2}{*}{ North-East (III) } & Białystok & -0.9 & 82.8 & 6.6 & 3.2 \\
\hline & Suwałki & -1.6 & 86.2 & 6.5 & 4.3 \\
\hline \multirow{4}{*}{ Central (IV) } & Toruń & 1.0 & 80.7 & 6.4 & 3.3 \\
\hline & Warszawa & 0.5 & 80.3 & 6.3 & 4.3 \\
\hline & Wrocław & 2.5 & 76.2 & 6.2 & 4.3 \\
\hline & Zielona Góra & 1.5 & 81.8 & 6.3 & 3.7 \\
\hline \multirow{2}{*}{ South-East (V) } & Lublin & -0.4 & 82.5 & 6.5 & 3.8 \\
\hline & Terespol & -0.4 & 80.5 & 6.6 & 3.5 \\
\hline \multirow{2}{*}{ Upland (VI) } & Kraków & 1.1 & 79.0 & 6.1 & 4.2 \\
\hline & Rzeszów & 0.6 & 79.3 & 6.4 & 5.2 \\
\hline \multirow{2}{*}{ Sudetic (VII) } & Jelenia Góra & 1.9 & 74.3 & 6.1 & 3.4 \\
\hline & Śnieżka & -5.4 & 85.1 & 6.3 & 14.2 \\
\hline \multirow{2}{*}{ Carpathian (VIII) } & Zakopane & -0.1 & 71.2 & 5.9 & 2.0 \\
\hline & Kasprowy Wierch & -6.7 & 81.6 & 6.0 & 7.4 \\
\hline
\end{tabular}

Source: own elaboration

Thermal stress in Poland in the winter season

In Poland, the most frequently recorded class of thermal stress in the winter season was moderate cold stress. In the lowland part of the country, this occurred with a mean frequency from $45.8 \%$ in Łeba to $66.1 \%$ in Zielona Góra. In Jelenia Góra and Zakopane, this class of thermal stress was recorded on $50.2 \%$ and $55.1 \%$ of days in winter months, and on Śnieżka and Kasprowy Wierch, its frequency was only $7.3 \%$ and $12.3 \%$ of days, respectively. At the majority of the analysed stations, the second most frequent class of thermal stress was strong cold stress. Such cases were recorded on an average of $11.1 \%$ of days in the winter season in Zakopane and on $43.4 \%$ of days in Suwałki. In Świnoujście, Zakopane, and Jelenia Góra, mild cold stress, with a frequency on the three aforementioned stations of $22.5-26.5 \%$, was recorded more frequently than strong cold stress. On high mountain stations, high frequency of thermal stress was also observed: very strong cold stress $(25.0 \%$ on Śnieżka and $35.5 \%$ on Kasprowy Wierch) and extreme cold stress $(17.7 \%$ on Kasprowy Wierch and $52.0 \%$ on Śnieżka). At the remaining stations, very strong cold stress was recorded on average in a range from $0.1 \%$ of days in the winter season in Zakopane to $5.7 \%$ of days in Łeba, and $7.4 \%$ of days in Rzeszów. In addition to high mountain stations, single cases of extreme cold stress were sporadically recorded. The last class that occurred during winter months was the thermoneutral zone. Thermoneutral conditions were the most frequently recorded in Świnoujście (2.1\%), Jelenia Góra (3.1\%), Kraków (3.6\%), and Zakopane $(4.3 \%)$. Only $2-3$ such cases throughout the multiannual period were observed in Chojnice, Suwałki, and Białystok. No such case was recorded on high mountain stations (Fig. 2).
Thermoneutral zone in Poland in the winter season

Comfort conditions are considered those of the atmospheric environment for which physiological thermoregulation processes are sufficient to maintain the heat balance of the organism. This state corresponds with conditions in which UTCI values vary from 9.1 to $26.0^{\circ} \mathrm{C}$ (Table 1). In the territory of Poland in winter, such situations are rare. An average of more than two days with no thermal stress was only recorded at three stations in the winter season. Two of the stations, namely Zakopane and Jelenia Góra, are located in valleys within mountain regions. A similar location is characteristic of the station in Kraków, representing the Upland region. At the station in Kraków, the number of cases that fell in the thermoneutral zone for two seasons was equal to or higher than 10 days (Fig. 3 ). In the 2006/2007 season, 12 such days occurred, of which 8 were recorded in December; and in the 2013/2014 season, 5 out of 10 days were observed during which thermal comfort occurred in February. At the remaining stations, such situations occurred considerably more seldom. Among the stations representing the lowland regions of Poland, Świnoujście was noteworthy, where an average of 1.9 days of thermal comfort conditions occurred in the winter season.

Strong cold stress categories (SCS+VSCS+ECS) in the winter season

In the winter season, the information that is important for a person in an open area is the frequency of occurrence of thermal stress that may lead to hypothermia. In the case of classes of thermal stress, namely mild and moderate cold stress, ways of dealing with unfavourable biothermal conditions include covering body parts prone to hypothermia (face and extremities), as well 


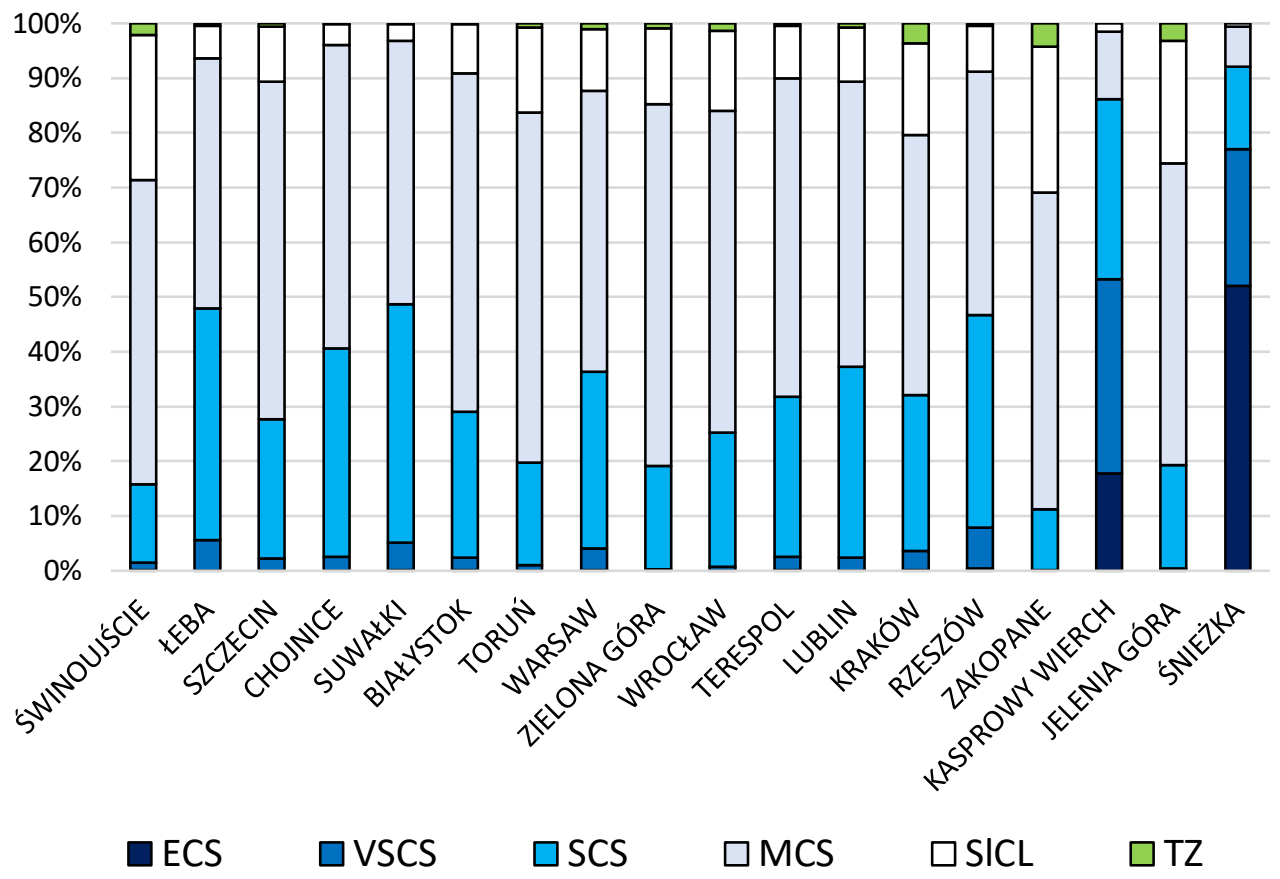

Figure 2. Frequency (\%) of various thermal stress categories (UTCI) at 12.00 UTC during winter season (DJF) in Poland, 2001/02 2017/18 (Source: own elaboration)

as increasing physical activity. During weather situations with potential thermal stress, from strong cold stress to extreme cold stress, it is recommended that clothing with increased thermoinsulation and wind-proof properties is worn, and that the time spent in the external environment is limited (Table 1).

At two stations representing the Coastal region, high differences were observed in the number of days in which thermal stress classes fell into strong cold stress categories. In Świnoujście, an average of 14 such days was recorded, and in Łeba, the number was three times higher (43 days). In the multiannual course, in Świnoujście, this thermal stress categories occurred from five times in the 2007/2008, 2014/2015 and $2017 / 2018$ seasons to 27 times in the $2009 / 2010$ season. In Łeba, the number of days classed as strong cold stress varied from 24 in the 2008/2009 season to 62 in the 2010/2011 season (Fig 4.). The tendency of the changes in the number of days classed in strong cold stress categories on both of the stations discussed was different. In Świnoujście, a negative trend was recorded, and in Łeba, a slightly positive trend. The trends were not statistically significant in either case.

High contrasts were also observed in the Sudetic and Carpathian mountain regions. In mountain valleys, strong cold stress categories were recorded on average 10 times in Zakopane and 17 times in Jelenia Góra. In Zakopane, the highest number of such cases (20 days) was in 2011/2012 season. Slightly fewer cases (14 days) occurred in the 2003/2004 and the 2009/2010 seasons. In Jelenia Góra in the 2004/2005, $2005 / 2006,2009 / 2010,2010 / 2011$ and $2012 / 2013$ seasons, the number of days in the strong cold stress categories ranged from 24 to 27 . At high mountain stations, such situations occurred on 78-83 days on average in a season with a higher frequency in the Sudety Mountains. The highest number of 88 such cases occurred on Śnieżka in seasons: 2006/2007 and 2011/2012 (Fig. 5). With the exception of the stations on Kasprowy Wierch and Jelenia Góra, the trends showing changes in the number of days in strong cold stress categories were negative. None of them were statistically significant.

In the remaining regions of Poland, a small number of days falling in strong cold stress categories was characteristic of stations of the Central region, particularly Zielona Góra and Toruń, where an average of 17-18 such days were recorded (Fig. 6). In Rzeszów, representing the Upland region, and in Suwałki (Fig. 7), representing the North-East region, the average number of days classed as strong cold stress was more than two times higher (42-44 days). At most stations during the period analysed, the highest number of cases in strong cold stress categories was in the 2010/2011 season. In this season, in Białystok and Toruń, the number of such days was about two times higher than the multi-annual average. In the multi-annual period analysed, a decrease in the number of days classed in strong cold stress categories was observed in the Lakeland (II), North-East (III), Central (IV), South-East (V), and Upland (VI) regions. The trends determined for the stations proved statistically significant in four cases: in Suwałki and Warszawa $(\alpha=0.05)$, and in Toruń and Lublin ( $\alpha=0.1)$.

At the stations analysed, cases of strong cold stress were observed at temperature values from $-25.7^{\circ} \mathrm{C}$ (Kasprowy Wierch - Carpathian region) to $11^{\circ} \mathrm{C}$ (Łeba - Coastal region). In the North-East and South-East regions, as well as the Carpathian and Sudetic regions (with the exception of Jelenia Góra), $75 \%$ of cases of thermal stress related to strong cold stress occurred at negative temperatures. At the majority of stations in the aforementioned regions (with the exception of stations located in mountain valleys), the lowest air temperature values were lower than $-20^{\circ} \mathrm{C}$. Higher temperature values during strong cold stress conditions were observed at the stations of the Coastal, Lakeland and Upland regions, and in Wrocław and Jelenia Góra (Fig. 8a).

Humidity conditions during thermal stress from the group of strong cold stress categories were variable, whereas at the majority of stations, situations when relative humidity was higher 


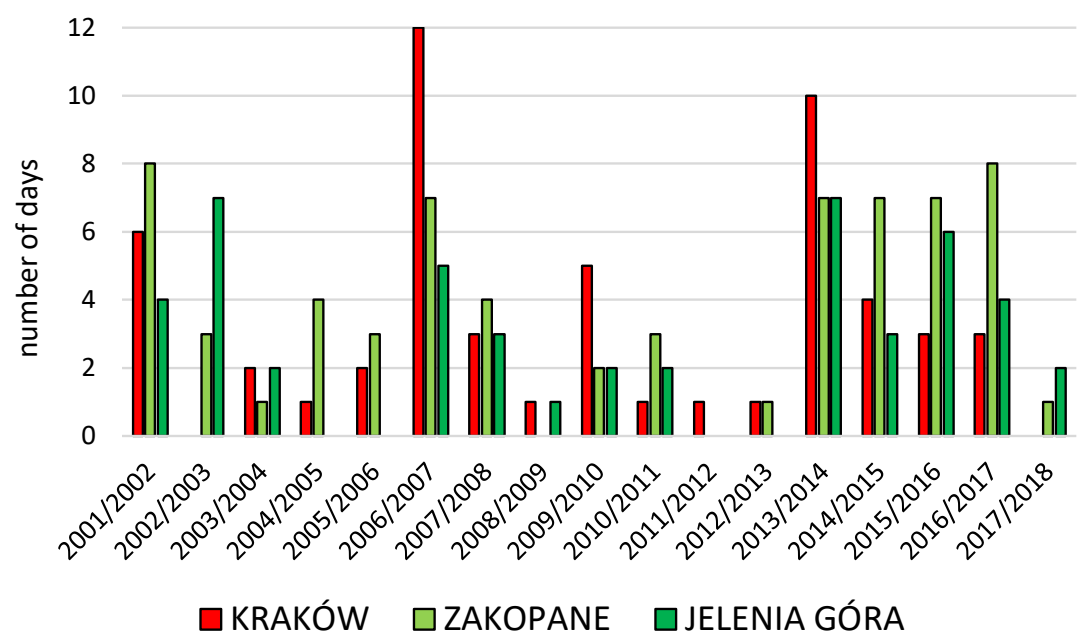

Figure 3. Number of days in thermoneutral category at 12.00 UTC in winter season (DJF) in selected meteorological stations in Poland, 2001/02 - 2017/18 (Source: own elaboration)

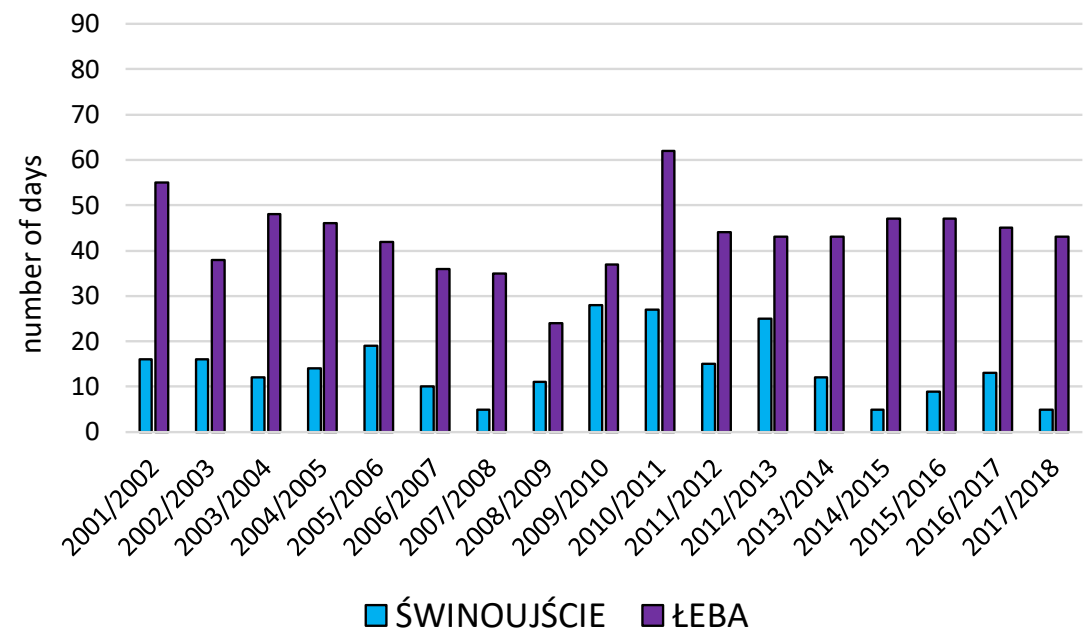

Figure 4. Number of days in strong cold stress categories (SCS+VSCS+ECS) at 12.00 UTC in the winter season (DJF) in the Coastal region, 2001/02 - 2017/18 (Source: own elaboration)

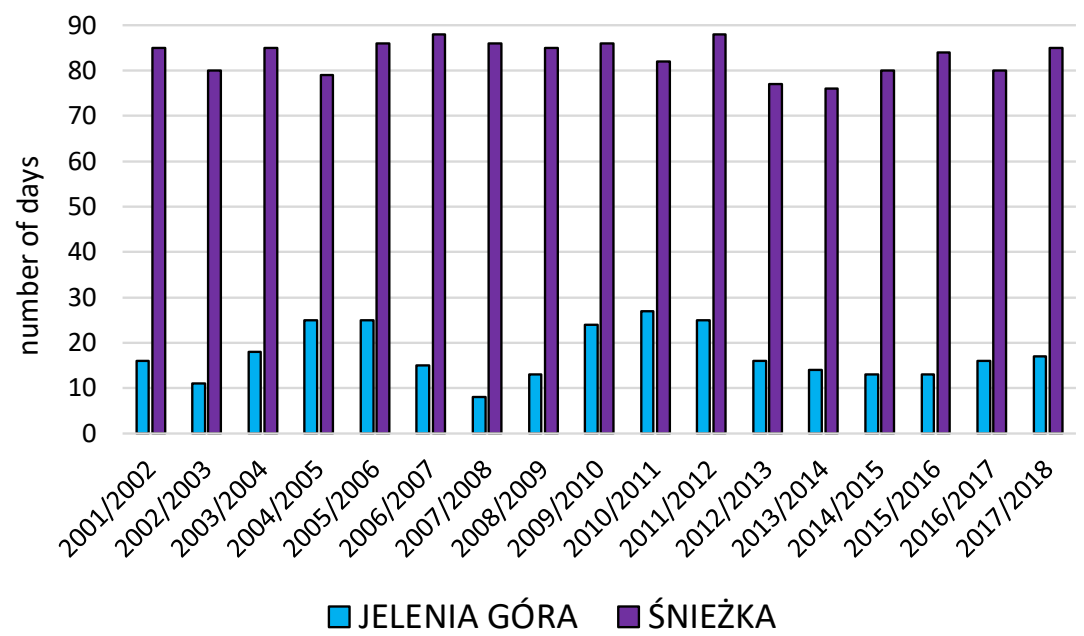

Figure 5. Number of days in strong cold stress categories (SCS+VSCS+ECS) at 12.00 UTC in the winter season (DJF) in the Sudetic region, 2001/02 - 2017/18 (Source: own elaboration) 


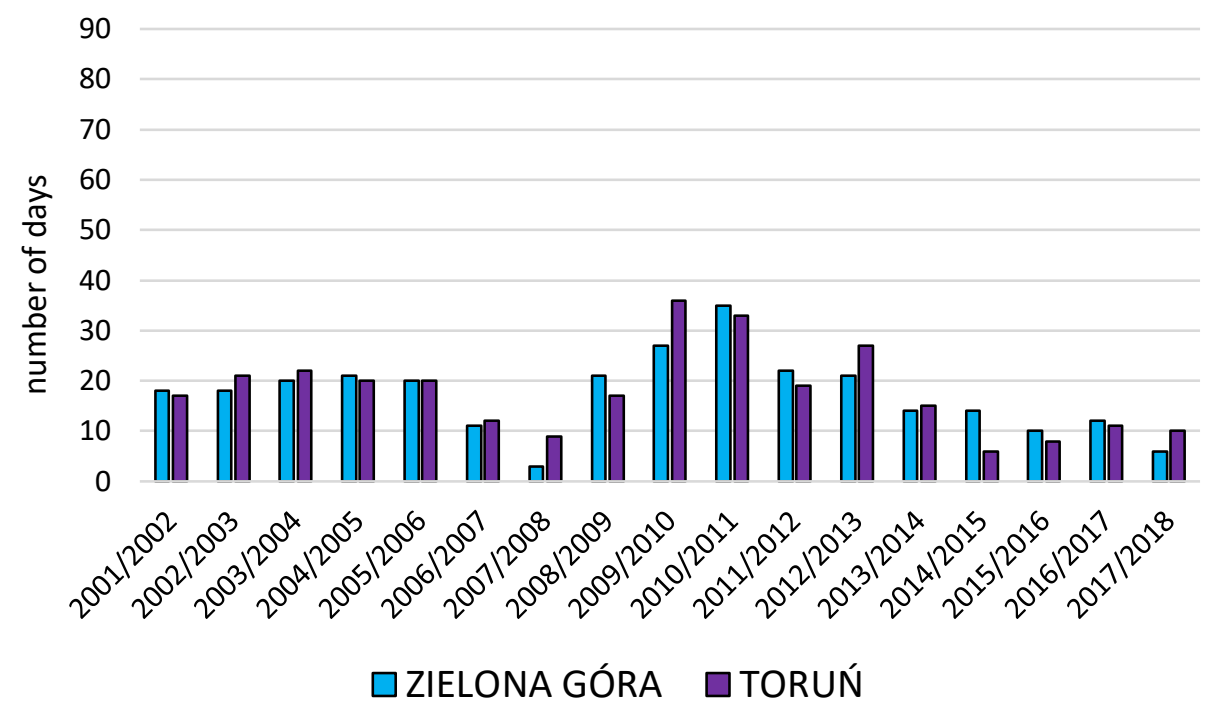

Figure 6. Number of days in strong cold stress categories (SCS+VSCS+ECS) at 12.00 UTC in the winter season (DJF) at selected meteorological stations in the Central region, 2001/02 - 2017/18 (Source: own elaboration)

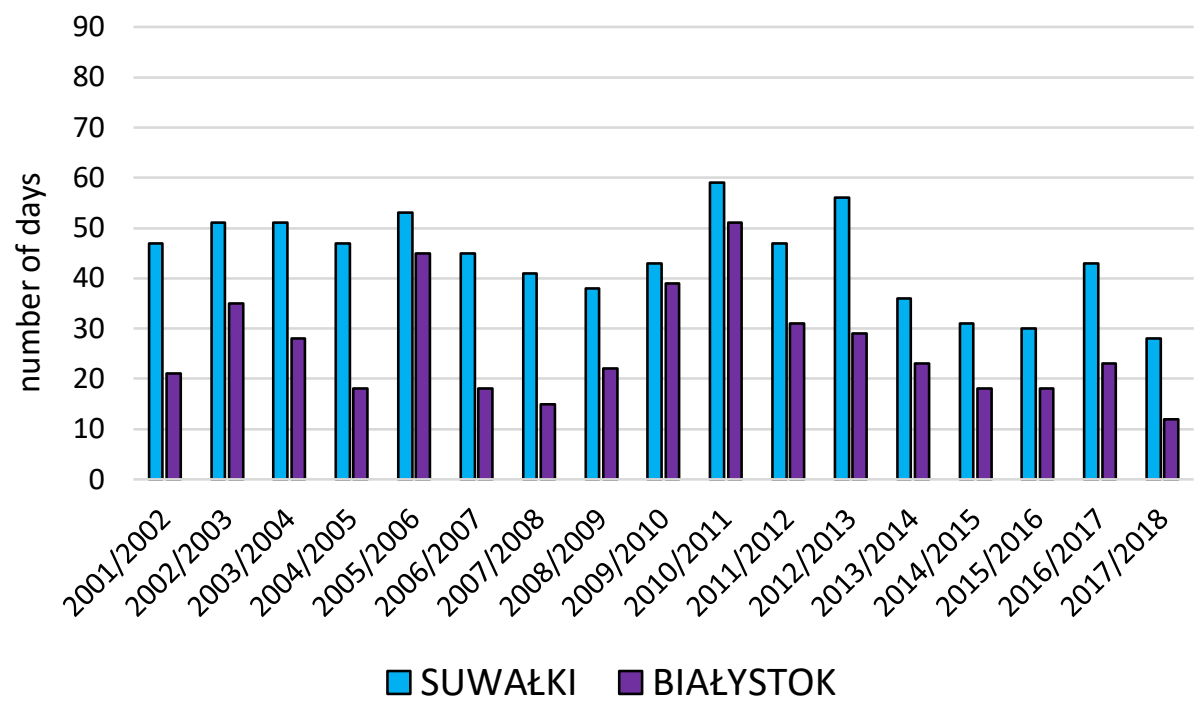

Figure 7. Number of days in strong cold stress categories (SCS+VSCS+ECS) at 12.00 UTC in the winter season (DJF) in the NorthEast region, 2001/02 - 2017/18 (Source: own elaboration)

than $70 \%$, and on Śnieżka higher than $80 \%$, were prevalent ( $75 \%$ of cases, Fig. $8 \mathrm{~b})$. The analysis of anemometric conditions draws attention to stations located in the belt of the Baltic coast and high mountain stations. Both in Łeba and in Szczecin, as well as on Kasprowy Wierch, $75 \%$ of thermal stress cases in the strong cold stress category occurred at a wind speed equal to or higher than $5 \mathrm{~m} \cdot \mathrm{s}^{-1}$; and on Śnieżka such conditions developed at a wind speed equal to or higher than $10 \mathrm{~m} \cdot \mathrm{s}^{-1}$. At the last of the aforementioned stations, $25 \%$ of cases occurred at a wind speed equal to or higher than $20 \mathrm{~m} \cdot \mathrm{s}^{-1}$ (Fig. 8c). At the majority of stations, the occurrence of thermal stress from the strong cold stress category was usually (in $75 \%$ of cases) accompanied by cloudiness equal to or higher than 7 octanes. Only at high mountain stations and in Świnoujście, was the cloudiness value equal to or higher than 5 octanes (Fig. 8d).
Discussion and conclusions

In the winter season in Poland, spatial variability of bioclimatic conditions is observed. This was emphasised by Błażejczyk and Kunert (2011). According to the authors of this paper, as in summer, the differences are also very evident in winter. Thermoneutral situations in this season of the year occur sporadically, and are particularly limited to four stations: Świnoujście, Kraków, Zakopane, and Jelenia Góra. The class of moderate cold stress, in the western part of the country (Zielona Góra) recorded on an average of $2 / 3$ days per season, is the most frequently observed. A high share of such days also occurs at stations in mountain valleys (more than $50 \%$ of all cases in a season).

In winter, the most unfavourable conditions for the human organism are those where thermal stress was recorded in the strong cold stress category. These usually occur at high 

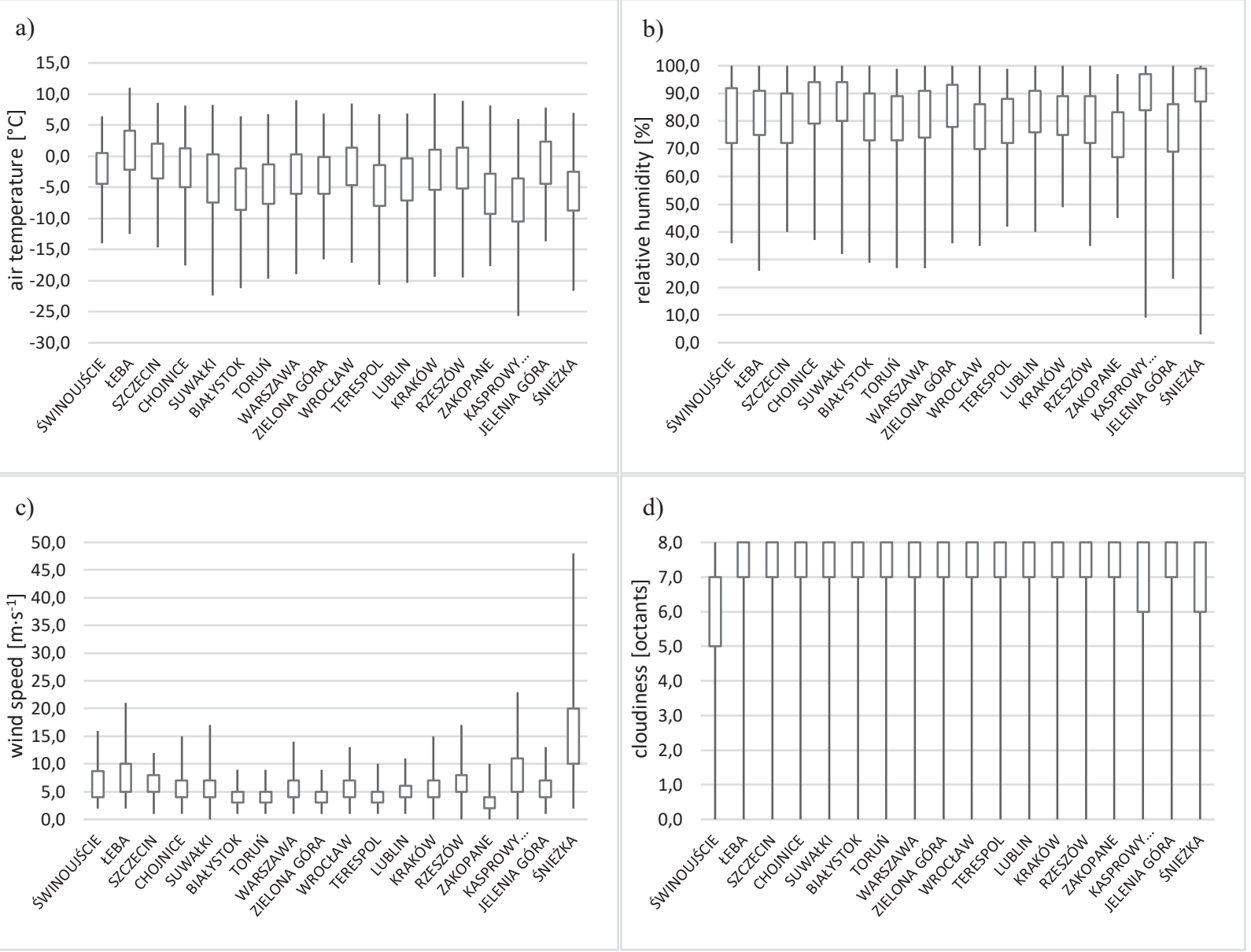

Figure 8. Selected measures of location (lower and upper quantile) and range (minimum and maximum) of air temperature, relative humidity, wind speed and cloudiness during strong cold stress (SCS + VSCS + ECS) in Poland in the winter season (DJF) (Source: own elaboration)

mountain stations. On Kasprowy Wierch and on Śnieżka, this was observed on an average of 78-83 days in a season. Such situations are recorded considerably more seldom in Jelenia Góra and Zakopane (10-17 days in a season). This is related to local conditions due to the location of the stations in the mountain valleys. Also, Miszuk et al. (2016) point to substantial differences in the frequency of strong to extreme cold stress between the station in Jelenia Góra ( $20 \%$ of days analysed) and Śnieżka ( $70 \%$ of days analysed). In addition, it is worth mentioning the results of research for Hala Gąsiennicowa in the Tatra Mountains, where strong cold stress categories were recorded in approximately $45 \%$ of cases in the winter season (Błażejczyk \& Kunert 2010). In the remaining regions of Poland, the effect of local conditions on the frequency of the occurrence of this category of thermal stress is also evident. At stations in the Coastal region (Świnoujście and Łeba), $14-43$ days of UTCI $\leq 13^{\circ} \mathrm{C}$ were recorded. This was emphasised by Koźmiński and Michalska (2019), pointing to a considerable disproportion in the frequency of the occurrence of thermal stress from the strong cold stress category at the Świnoujście and Ustka stations. A similar situation occurred in the Upland region, where the difference between the stations in Kraków and Rzeszów was 13 days, and in the North-East region, where 18 such days more than in Białystok were observed in Suwałki. According to Błażejczyk and Kunert (2011), in January, the conditions of occurrence of strong cold stress are considerably more frequently recorded in the northern and central part of the country, where their frequency can reach up to $30-40 \%$ in a month.

Next to local factors, the development of local bioclimatic conditions of the winter season is largely determined by the location of Poland in the zone of oceanic and continental influences, leading to the meridional course of isotherms in this season of the year (Paszyński \& Niedźwiedź 1999). This is also evident in the spatial distribution of the mean number of days of thermal stress in the strong cold stress category. In Zielona Góra, located in the west of the country, such days occurred on average 17 times per season, and in Terespol or in Lublin, located in eastern Poland, approximately 30 such days were recorded.

In the period of modern climate change, a decrease in the number of extreme events related to low air temperature was observed (IPCC 2014). This is confirmed by the decreasing tendency of the number of days classed in strong cold stress categories in the winter season observed at the majority of stations. At four out of the 18 analysed stations, the trend determined proved statistically significant. These changes were already observed at selected stations in Poland in the second half of the 20th century. In Poznan and Kołobrzeg, the number of days that fall in the strong and very strong cold stress categories 
decreased in January by more than $20 \%$, with a simultaneous increase in the frequency of days of moderate cold stress (Okoniewska \& Więclaw 2012). Also, research conducted for Warsaw (Błażejczyk et al. 2013) and Poland (Błażejczyk et al. 2015; Kuchcik 2017) confirms that in recent decades the number of days classed in strong cold stress categories decreased. In years 1966-2012 this number decreased from about 60 at the beginning of this period to about 30 in recent years. Based on different climate change SRES scenarios, a systematic increase of the mean annual UTCI value is predicted in Poland by 2100 . Consequently, there will be a decrease in the number of days that fall in strong cold stress categories. Assuming that during the 1991-2000 period such days were observed on 10 days of the year, at the end of 21st century these are predicted to occur on $6.0-7.7 \%$ of the days of the year, depending on the climate change scenario (Błażejczyk et al. 2015). It should be remembered, however, that such phenomena will keep occurring, although their frequency and intensity will be considerably lower. This is particularly important because, as a result of the changes described, our society will be less adapted to biothermal conditions, which cause the cooling of the human body, and in the case of such conditions, health consequences may be very severe.

The results presented, in the context of possible risks, may be a source of information for governmental institutions, nongovernmental organisations and emergency services who work on adaption procedures related to current and future climate changes.

\section{ORCID}

Sylwester Wereski (iD https://orcid.org/0000-0003-4726-0363

Agnieszka Krzyżewska (1) https://orcid.org/0000-0002-4358-059X

Mateusz Dobek (D) https://orcid.org/0000-0001-5614-436X

\section{References}

Anagnostopoulou, C, Tolika, K, Lazoglou, G \& Maheras, P 2017, 'The exceptionally cold January of 2017 over the Balkan Peninsula: A climatological and synoptic analysis' Atmosphere, vol. 8, no 12, 252.

Błażejczyk, K, Baranowski, J \& Błażejczyk, A 2015, Influence of climate on health status in Poland and projection to the year 2100, Wydawnictwo Akademickie SEDNO, IGiPZ PAN, Warsaw.

Błażejczyk, K, Idzikowska, D \& Błażejczyk, A 2013, 'Forecast changes for heat and cold stress in Warsaw in the 21st century, and their possible influence on mortality risk', Papers on Global Change IGBP, vol. 20, pp. 47-62.

Błażejczyk, K, Jendritzky, G, Bröde, P, Fiala, D, Havenith, G, Epstein, Y, Psikuta, A \& Kampmann, B 2013, 'An introduction to the Universal Thermal Climate Index (UTCI)' Geographia Polonica, vol. 86, no. 1, pp. 5-10.

Błażejczyk, K \& Kunert, A 2010, 'Heat load in man during Summer and Winter pedestrian tourism in the Tatry Mts' in Science and management of the Tatra Mountains area and their surroundings. vol .3. Man and environment. $4^{\text {th }}$ Conference Nature of the Tatra National Park and Men, Zakopane, 1416 October 2010, eds Z Krzan, Tatrzański National Park, Zakopane, pp. 61-68.

Błażejczyk, K \& Kunert, A 2011, 'Bioclimatic principles of recreation and tourism in Poland' Monographies, vol. 13 IGiPZ PAN, Warsaw.

Cattiaux, J, Vautard, R, Cassou, C, You, P, Masson-Delmotte, V \& Codron, F 2010, 'Winter 2010 in Europe: A cold extreme in a warming climate', Geophysical Research Letters, vol. 37, pp. 1-6.

Cebulak, E \& Limanówka, D 2007, 'Days with extreme air temperatures in Poland' in Climate variation at various scales of time and space, eds K Piotrowicz \& R Twardosz, IGiGP UJ, Kraków, pp. 185-194.

Chabior M 2011, 'Selected aspects of the bioclimate of Szczecin', Studies in Geography, vol. 47, pp. 293-300.

Fiala, D, Havenith, G, Bröde, P, Kampmann, B \& Jendritzky, G 2012, 'UTCl-Fiala multi-node model of human heat transfer and temperature regulation', International Journal of Biometeorology, vol. 56, no. 3, pp. 429-441.

Fiala, D, Lomas, KJ \& Stohrer, M 2001, 'Computer prediction of human thermoregulatory and temperature responses to a wide range of environmental conditions', International Journal of Biometeorology, vol. 45, no. 3, pp. 143-159.

Ge, Q, Kong, Q, Xi, J \& Zheng, J 2017, 'Application of UTCI in China from tourism perspective', Theoretical and Applied Climatology, vol. 128, no. 3-4, pp. 551-561.
Healy JD 2003, 'Excess winter mortality in Europe: a cross country analysis identifying key risk factors', Journal of Epidemiology \& Community Health, vol. 57, no. 10, pp.784-789.

IPCC 2014, Climate Change 2014: Synthesis Report, Contribution of Working Groups I, II and III to the Fifth Assessment Report of the Intergovernmental Panel on Climate Change, Core Writing Team, eds RK Pachauri \& LA Meyer, IPCC, Geneva, Switzerland

Instytut Geografii i Przestrzennego Zagospodarowania Polskiej Akademii Nauk 2019, BioKlima Software. Available from: $\quad<$ https://www.igipz.pan.pl/Bioklima-zgik.html> [11 February 2019].

Jendritzky, G, de Dear, R \& Havenith, G 2012, 'UTCI-Why another thermal index?', International Journal of Biometeorology, vol. 56, no. 3, pp. 421-428.

Jendritzky, G, Havenith, G, Weihs, P \& Batchvarova, E (eds) 2009, 'Towards a Universal Thermal Climate Index UTCI for assessing the thermal environment of the human being', Final Report COST Action 730. Available from: <www.utci. org/cost.php>. [11 February 2019].

Kozłowska-Szczęsna, T, Błażejczyk, K \& Krawczyk, B 1997, 'Human bioclimatology. Methods and applications', Monographies, vol. 1, IGiPZ PAN, Warsaw.

Koźmiński, C \& Michalska, B 2019, 'Assessment of bioclimatic conditions for recreation and tourism in the Polish Baltic coastal zone using the UTCI index', Polish Geographical Review, vol. 91, no. 2, pp. 113-126.

Krzyżewska, A \& Wereski, S 2011, 'Heat waves and frost waves in selected polish stations against bioclimatic regions background (2000-2010)', Przegląd Geofizyczny, vol. 56, no. 1-2, pp. 99-109.

Krzyżewska, A, Dobek, M, Domżał-Drzewicka, R \& Rząca, M 2017, 'Emergency interventions due to weather related hypothermia', Weather, vol. 72, no. 1, pp. 8-12.

Krzyżewska, A, Wereski, S \& Nowosad, M 2019, 'Thermal variability in the Lublin region during the frost wave in January 2017', Annales UMCS, sec. B, vol. 74, no. 1, pp. 217-229.

Kuchcik, M 2017, 'Thermal conditions in Poland at the turn of the $20^{\text {th }}$ and $21^{\text {st }}$ centuries, and their impact on mortality', Geographical Studies, no. 263.

Mąkosza A 2013, 'Bioclimatic conditions of the Lubuskie Voivodeship', Geographia Polonica, vol. 86, no. 1, pp. 3746.

Milewski P 2013, 'Application of the UTCI to the local bioclimate of Poland's Ziemia Kłodzka region', Geographia Polonica, vol. 86 , no. 1 , pp. $47-54$. 
Miszuk, B, Otop, I, Strońska, M, Schwarzak, S \& Surke, M 2016, 'Tourism-climate conditions and their future development in the Polish-Saxon border area', Meteorologische Zeitschrift, vol. 25 , no. 4, pp. 421-434.

Mladenović, MB, Gombás, K, Liška, I \& Balatonyi L 2017, 'Report on the Ice Event 2017 in the Danube', International Commission for the Protection of the Danube River. Available from: <https://www.icpdr.org/main/sites/default/ files/nodes/documents/report_ice_event_2017_lowres. pdf>. [17 April 2019].

Mohammadi, B, Gholizadeh, MH \& Alijani, B 2018, 'Spatial distribution of thermal stress in Iran based on PET and UTCI indices', Applied Ecology and Environmental Research, vol. 16 , no. 5 , pp. 5423-5445.

Novak, M 2013, 'Use of the UTCI in the Czech Republic', Geographia Polonica, vol. 86, no. 1, pp. 21-28.

Okoniewska, M \& Więcław, M 2013, 'Long-term variability of bioclimatic conditions in the second half of the 20 century at noon hours in Poland based on Universal Thermal Climate Index', Journal of Health Sciences, vol. 3, no. 15, pp. 116131.

Owczarek, M 2019, 'The influence of large-scale factors on the heat load on human beings in Poland in the summer months', Theoretical and Applied Climatology, vol. 137, no. 1-2, pp. 855-869.

Owczarek, M, Marosz, M \& Kitowski, M 2019, 'The influence of atmospheric circulation on the occurrence of heat stress on human beings on the Polish coast of the Baltic Sea' in Climate variability in Poland and Europe and its circulation conditions, eds L Kolendowicz, E Bednorz \& AM Tomczyk, Bogucki Wydawnictwo Naukowe, Poznań, pp. 135-156.

Paszyński, J \& Niedźwiedź, T 1999, 'Climate' in Geography of Poland. The natural environment, ed. L Starkel, PWN, Warsaw, pp. 288-343.

Provençal, S, Bergeron, O, Leduc, R \& Barrette, N 2016, 'Thermal comfort in Quebec City, Canada: sensitivity analysis of the UTCl and other popular thermal comfort indices in a mid-latitude continental city', International Journal of Biometeorology, vol. 60, no. 4, pp. 591-603.

Schulze, D, Glowacka, A, Müller, E, van den Born R et al. 2018, Winter 2017/2018. European End-of-Season Report. MeteoGroup, Available from: <https://www.meteogroup.com/ sites/default/files/meteogroup_winter_report_2017-2018. pdf>. [17 April 2019].

Tomczyk, AM \& Bednorz, E 2019, 'The extreme year - analysis of thermal conditions in Poland in 2018', Theoretical and Applied Climatology, vol. 139, pp. 251-260.

Tomczyk, AM, Bednorz, E \& Sulikowska, A 2019 'Cold spells in Poland and Germany and their circulation conditions', International Journal of Climatology, vol. 39, no. 10, pp. 4002-4014.

Tomczyk, AM \& Owczarek, M 2020. 'Occurrence of strong and very strong heat stress in Poland and its circulation conditions', Theoretical and Applied Climatology, vol. 139, no 3-4, pp. 893-905.

Twardosz, R \& Kossowska-Cezak, U 2016, 'Exceptionally cold and mild winters in Europe (1951-2010)', Theoretical and Applied Climatology, vol. 125, no. 1-2, pp. 399-411.

Twardosz, R, Kossowska-Cezak, U \& Pełech, S 2016, 'Extremely Cold Winter Months in Europe (1951-2010)', Acta Geophysica, vol. 64, no. 6, pp. 2609-2629.

Vajda, A, Tuomenvirta, H, Juga, I, Nurmi, P, Jokinen, P \& Rauhala, J 2014, 'Severe weather affecting European transport systems: The identification, classification and frequencies of events' Natural Hazards, vol. 72, no. 1, pp. 169-188. 